\title{
Peranan Komitmen dan Komunikasi Interpersonal Dalam Meningkatkan Kepuasan Pernikahan pada Suami yang Memiliki Istri Bekerja
}

\author{
Sofa Raihana Harahap, Yuliana Intan Lestari
}

Fakultas Psikologi Universitas Islam Negeri Sultan Syarif Kasim Riau

email: riska.ade.irma@uin-suska.ac.id; raudatussalamah@uin-suska.ac.id

\begin{abstract}
Abstrak
Kepuasan pernikahan menjadi salah satu faktor terpenting untuk mencapai keluarga yang bahagia. Fenomena saat ini, banyak suami yang merasakan ketidakpuasan dengan pernikahannya karena memiliki istri bekerja. Hal ini akan memicu terjadinya masalah dalam pernikahan. Untuk itu diperlukan adanya komitmen dan komunikasi interpersonal agar tercapainya kepuasan pernikahan. Tujuan penelitian ini untuk mengetahui hubungan komitmen dan komunikasi interpersonal dengan kepuasan pernikahan pada suami yang memiliki istri bekerja.Subjek penelitian adalah suami yang memiliki istri yang bekerja di Kelurahan Simpang Baru Pekanbaru sebanyak 110 subjek, menggunakan teknik Total Sampling.Pengumpulan data mengunakan Skala Komitmen, Skala Komunikasi Interpersonal dan Skala Kepuasan Pernikahan. Analisis data mengunakan teknik Regresi Bergandadengan bantuan program SPSS 22.0 for windows. Hasil analisis regresi ganda diperoleh nilai $F$ sebesar 15,284 dengan hasil signifikansi sebesar $0,000(p<0,01)$ artinya hipotesis dalam penelitian ini diterima yaitu terdapat hubungan antara komitmen dan komunikasi interpersonal dengan kepuasan pernikahan pada suami yang memiliki istri bekerja.
\end{abstract}

Kata kunci:komitmen. Komunikasi interpersonal,kepuasan pernikahan

\section{The Role of Commitment and Interpersonal Communication In Improving Marital Satisfaction on Husbands that have a Wife Working}

\begin{abstract}
Marital satisfaction is one of the most important factors to achieve a happy family. The current phenomenon, many husbands feel dissatisfaction with their marriage because they have a working wife. This will trigger problems in marriage. For this reason, it requires commitment and interpersonal communication to achieve marital satisfaction. The purpose of this study was to determine the relationship of commitment and interpersonal communication with marital satisfaction on the husband who has a working wife. Research subjects on the husband who has a working wife were 110 subjects, using Total Sampling technique. Data collection uses Commitment Scale, Interpersonal Communication Scale and Wedding Satisfaction Scale. Data analysis uses Multiple Regression techniques with the help of SPSS 22.0 for Windows program. The results of multiple regression analysis obtained an $\mathrm{F}$ value of 15.284 with a significance result of $0.000(p<0.01)$ which means that the hypothesis in this study is accepted, namely there is a relationship between commitment and interpersonal communication with marital satisfaction in the husband who has a working wife.
\end{abstract}

Keywords: Commitment, Interpersonal Communication, Marital Satisfaction

\section{Pendahuluan}

Wanita selalu diidentikkan dengan melahirkan, membersihkan rumah, mencuci, pakaian, memasak, mengurus anak, dan mengurus pekerjaan rumah lainnya. Wanita dulu tidak dibolehkan bekerja di luar rumah, namun seiring dengan pesatnya pertumbuhan dan perkembangan ekonomi yang terjadi dalam beberapa dekade ini membuat tuntutan sosial ekonomi dalam keluarga semakin tinggi. Hal ini yang menyebabkan banyak para istri memilih untuk bekerja. Bermacam alasan 
yang menyebabkan istri bekerja, antara lain untuk memenuhi kebutuhan ekonomi keluarga, mengaplikasikan ilmu pendidikan yang didapat, atau adanya keinginan untuk mengembangkan potensi yang dimiliki.

Peran wanita adalah sebagai istri, sebagai ibu dan sebagai pengurus rumah tangga, akan tetapi seiring dengan perkembangan zaman dan tuntutan ekonomi, banyak wanita yang turut bekerja dengan ruang lingkup di dalam maupun di luar rumah dan berbagai faktor yang melatarbelakanginya Munandar (dalam Pertiwi, 2006). Tidak jarang dijumpai para suami setuju untuk istri bekerja diluar rumah, dengan alasan dapat menambah sumber financial keluarga, namun tidak sedikit pula suami yang tidak setuju dengan istri bekerja di luarrumah karena berbagai alasan, misalnya segalapekerjaan rumah menjadi terabaikan, pengasuhan istri terhadap anak menjadi tidakmaksimal atau tidak maksimal dalam melayani suami. Hal inilah yang menjadi pertimbangan segelintir suami untuk tidakmenginginkan istri bekerja diluar rumah (Paputungan, 2012). Adapun jumlah wanita yang bekerja di Indonesia sesuai dengan Sensus Penduduk pada tahun 2015 yaitu sebanyak 120,8 juta jiwa (Badan Pusat Statistik). Ketika isteri bekerja, peran suami juga bertambah dikarenakan adanya pembagian tugas rumah tangga. Suami telah menggandakan waktu untuk pekerjaan rumah tangga mulai dari di bawah 5 jam per minggu menjadi di atas 5 jam per minggu bahkan mencapai 14,5 jam per minggu (DeGenova dalam Daeng 2010).

Menurut Dalimunte (2013), mayoritas suami mengharapkan istri bertanggung jawab atas urusan rumah tangga dan anakanak, baik istri yang bekerja atau sebagai ibu rumah tangga. Suami menganggap dirinya harus mengembangkan karir dan mencukupi kebutuhan rumah tangga, sehingga hampir semua waktunya, dicurahkan untuk pengembangan karir dan mencari uang. Tidak jarang, istri tidak ada waktu lagi untuk suami dan anak, apalagi urusan rumah tangga. Dalimunte (2013) menjelaskan bahwa setiap individu yang memutuskan menikah, tentu menginginkan pernikahan yang bahagia, begitupun dengan para suami.

Tujuan perkawinan yang mulia adalah membina keluarga bahagia, kekal, abadi berdasarkan Ketuhanan Yang Maha Esa, maka terdapat pengaturan mengenai hak dan kewajiban suami istri masing-masing. Apabila terpenuhi, maka dambaan suami istri dalam kehidupan berumah tangga akan dapat terwujud karena didasari rasa cinta dan kasih sayang. Sebagaimana dijelaskan didalam Al-Qur'an Allah menyatakan bahwa pernikahan merupakan salah satu kebesaran Allah dan sekaligus karunia Allah yang wajib disyukuri.Caranya adalah dengan memberi cinta dan kasih sayang kepada anggota keluarga sehingga terbentuklah keluarga yang harmonis. Firman Allah dalam surat ArRum ayat 21 , yang artinya:

"Dan di antara tanda-tanda kekuasaan-Nya ialah dia menciptakan untukmu isteri-isteri dari jenismu sendiri, supaya kamu cenderung dan merasa tenteram kepadanya, dan dijadikan-Nya diantaramu rasa kasih dan sayang. Sesungguhnya pada yang demikian itu benar-benar terdapat tanda-tanda bagi kaum yang berfikir".

Kepuasan pernikahan adalah perasaan yang bersifat subjektif dari pasangan suami istri mengenai perasaan bahagia, puas, dan menyenangkan terhadap pernikahannya secara menyeluruh (Olson dan Fowers 2010).Pinson dan Lebow menyatakan bahwa kepuasan perkawinan adalah suatu pengalaman subjektif, suatu perasaan yang berlaku dan suatu sikap, dimana semua itu didasarkan pada faktor dalam diri individu yang mempengaruhi kualitas yang dirasakan dari interaksi dalam perkawinan (dalam Rini dan Retnaningsih, 2008).Kepuasan pernikahan menurut Clayton (dalam Ardhianita dan Andayani, 2004) merupakan evaluasi secara keseluruhan tentang segala hal yang berhubungan dengan kondisi pernikahan.

Berdasarkan teori yang dikemukakan oleh Olson dan Fowers (2010), aspekaspek kepuasan perkawinan terdiri dari: a) Komunikasi, aspek ini melihat bagaimana 
perasaan dan sikap individu terhadap komunikasi dalam hubungan mereka sebagai suami istri. b) Aktivitas Waktu Luang, aspek ini mengukur pada pilihan kegiatan yang dipilih untuk menghabiskan waktu senggang. c) Orientasi Keyakinan Beragama, aspek ini mengukur makna kepercayaan agama dan praktiknya dalam perkawinan. Nilai-nilai yang terkandung dalam agama merupakan bagian yang terpenting dalam perkawinan. d) Pemecahan Masalah, aspek ini berfokus pada keterbukaan pasangan terhadap isu-isu pengenalan dan penyelesaian, dan strategistrategi yang digunakan untuk menghentikan argumen, serta saling mendukung dalam mengatasi masalah bersama-sama dan membangun kepercayaan satu sama lain. e) PengaturanKeuangan, aspekiniberfokus pada sikap yang berhubungan dengan bagaimana cara pasangan mengelola keuangan. Aspek ini mengukur pola bagaimana pasangan membelanjakan uang yamg dimiliki dan perhatian pasangan terhadap keputusan finansial rumah tangga. f) Orientasi Seksual, aspek ini mengukur perasaan pasangan mengenai afeksi dan hubungan seksual mereka. Orientasi seksual menunjukkan sikap mengenai isu-isu seksual, perilaku seksual, kontrol kelahiran, dan kesetiaan. g) Keluarga dan Kerabat, aspek ini menunjukkan perasaan-perasan yang berhubungan denga relasi dengan anggota keluarga, keluarga dari pasangan, dan teman-teman. h) Peran menjadi orang tua, aspek ini mengukur sikap dan perasaan mengenai peran sebagai orang tua, kepemilikan, dan pengasuhan anak. i) Kepribadian pasangan, aspek ini mengukur persepsi individu mengenai karakter pribadi pasangan yang ditunjukkan dari tingkah laku. j) Peran dalam Keluarga, aspek ini mengukur perasaan-perasaan dan sikap-sikap individu mengenai peran-peran perkawinan dan keluarga.

Fenomena saat ini, suami yang merasa tidak puas dalam pernikahan dikarenakan kesibukan isteri bekerja maka suami akan merasakan kehilangan pelayanan dari seseorang yang bertanggung jawab dalam mengurus rumah tangga, seperti seseorang yang seharusnya berada di rumah pada saat mereka pulang, seseorang yang menyediakan makanan, dan seseorang yang mencuci dan menyetrika pakaian mereka. Hal inilah yang menimbulkan permasalahan pada diri suami (Papalia, Olds, \& Feldman, 2008). Ada pula suami yang tidak menganggap pekerjaan istri menjadi suatu masalah, selama istrinya tetap dapat memenuhi dan melayani kebutuhan suami dan anak. Namun, ada pula suami justru mendukung karir istrinya bahkan ikut membantu dalam mengurusi pekerjaan rumah tangga sehari-hari (Dalimunte, 2013).

Pasangan merasa tidak puas dengan pasangan dan hubungan pernikahannya tersebut, pada akhirnya pasangan menjadi rentan terhadap perselingkuhan (dalam Wulandari, 2014).Pasangan yang tidak merasakan kepuasan pernikahan cenderung menjadikan perceraian sebagai solusi untuk membangun hidup baru yang lebih bahagia.

Suami yang merasa tidak puas tetap mempertahankan pernikahannya.Hal ini dikarenakan adanya komitmen diawal pernikahan yang menjadi faktor penting didalam pernikahan. Menurut Robinson dan Blanton (2003) yang mengemukakan beberapa faktor terpenting dalam sebuah pernikahan yang memuaskan, antara lain: Keintiman, Komitmen, Komunikasi, Kongruensi dan Keyakinan beragama. Sejalan dengan pendapat Papalia, Olds \& Feldman, (2008) bahwa salah satu faktor terpenting kesuksesan pernikahan adalah perasaan akan adanya komitmen.

Komitmen pernikahan adalah suatu kesepakatan yang yang dibuat oleh pasangan suami istri (Johnson, Caughlin dan Huston,1991). Komitmen pernikahan adalah pengalaman dari pasangan suami istri yang bersama-sama untuk tetap mempertahankan pernikahannya sebagai fungsi, bagian, dan interaksinya (Thompson \& Webb, 2004). Rusbult, dkk (1986) menjelaskan bahwa komitmen adalah seberapa besar kecenderungan seseorang untuk melanjutkan hubungan dengan pasangannya, memandang masadepanakanterus bersamapasangannya, dan adanya kelekatan psikologis satu sama lain dengan pasangan (dalam Handayani, 2008).Aspek-aspek komitmen pernikahan, 
menurut Jhonson, Caughlin dan Huston (1991) terbagi tiga yaitu : a) Komitmen Pribadi yakni sejauh mana individu ingin tinggal dalam satu hubungan. b) Komitmen Moral berarti bahwa individu secara moral berkewajiban untuk melanjutkan hubungan perkawinan tersebut. c) Komitmen Struktural adalah keinginan bertahan dalam suatu hubungan karena adanya faktor penahan dalam hubungan tersebut yang menghambatnya untuk meninggalkan hubungan.

Selain komitmen pernikahan ada hal yang dapat mempengaruhi kepuasaan dalam pernikahan. Azeez (2013) melakukan penelitian terhadap wanita pekerja yang menemukan bahwa kepuasan pernikahan sangat dipengaruhi oleh keterampilan interpersonal dalam berkomunikasi dengan pasangan. Salah satu jenis komunikasi yang memiliki frekuensi cukup tinggi adalah komunikasi interpersonal. Menurut DeVito (1997) komunikasi interpersonal adalah pengiriman dan penerimaan pesan-pesan antara dua orang, atau diantara sekelompok kecil orang-orang, dengan beberapa efek dan beberapa umpan balik seketika.Tan (1981) mengemukakan bahwa komunikasi antarpribadi adalah komunikasi tatap muka antara dua atau lebih orang (dalam Liliweri, 1997). Menurut Devito (1997) kualitas umum komunikasi interpersonal meliputi: a)Keterbukaan: Ada ketersediaan untuk membuka diri, mengungkapkan informasi yang biasanya disembunyikan, asalkan memenuhi batas-batas kewajaran. b) Empati: Individu melihat dan merasakan oranglain seperti apa yang dirasakannya. c) Sikap Mendukung: Individu harus bisa memperlihatkan sikap mendukung dengan sikap. d) Sikap Positif: Komunikasi interpersonal terbina jika orang memiliki sikap positif terhadap dirinya sendiri. e) Kesetaraan: Harus ada pengakuan secara diam-diam bahwa kedua belah pihak samasama bernilai dan berharga, dan bahwa masing-masing pihak mempunyai sesuatu yang penting untuk disumbangkan.

Fenomena saat ini banyak istri yang bekerja terlalu sibuk dan terkadang lupa menjalin komunikasi dengan pasangan. Salah satu penyebab daribeberapa peristiwa pertengkaran, perselisihan, perdebatan, perkelahian, dansebagainya adalah karena adanya kesalahpahaman dalam berkomunikasi.Pasangan dengan komitmen yang tinggi akan selalu mengkomunikasikan segala permasalahan yang ada didalam pernikahan, berusaha untuk mencari solusi dan memecahkan masalah secara lebih efektif akan cenderung lebih baik, lebih puas dengan kehidupan daripada pasangan yang komitmennya rendah.

Bila semakin efektif komunikasi maka hubungan pasangan suami istri semakin harmonis.Oleh karena itu, komunikasi digunakan untuk membuat dan mengembangkan komitmen pernikahan (Thompson dan Webb, 2004). Meskipun komunikasiyangefektiftidak selalu ditunjukkan dari sering tidaknya melakukan komunikasi. Namun pasangan suami istri sama-sama bekerja dengan kesibukan masing-masing, keduanya berusaha untuk senantiasa melakukan komunikasi karena komunikasi ditunjukkan sebagai bentuk perhatian kepada pasangannya.

Berdasarkan uraian di atas penulis tertarik untuk meneliti tentang "Hubungan Komitmen Dan Komunikasi Interpersonal Dengan Kepuasan Pernikahan Pada Suami yang Memiliki Istri Bekerja". Hipotesis yang diajukan dalam penelitian ini yaitu terdapat hubungan antara komitmen dan komunikasi interpersonal dengan kepuasan pernikahan ada suami yang memiliki istri bekerja.

\section{Metode \\ Partisipan}

Populasi pada penelitian ini adalah suami yang memiliki istri bekerja di Kelurahan Simpang Baru Panam di Pekanbaru. Sampel penelitian berjumlah 110 orang suami yang memiliki istri yang bekerja. Teknik sampling yang digunakan adalah Total Samplingyakni teknik pengambilan sampel dimana jumlah sampel sama dengan populasi (Sugiyono, 2007). 


\section{Pengukuran}

Data dikumpulkan melalui 3 Skala yaitu skala komitmen berdasarkan konsepJhonson, Caughlin dan Huston (1991), skala komunikasi interpersonal menurut Devito (1997), dan skala kepuasan pernikahan menurut Olson dan Fowers (2010). Adapun jumlah aitem pada masing-masing skala adalah 19 aitem untuk skala kepuasan pernikahan, 15 aitem untuk skala komitmen dan 19 aitem untuk skala komunikasi interpersonal. Berikut contoh aitem dari skala komunikasi interpersonal Hasil
"Saya bersama isteri selalu mendiskusikan tentang masalah anak-anak". contoh aitem pada skala komitmen "Saya berjanji akan memberi yang terbaik untuk keluarga". Serta contoh aitem pada skala kepuasan pernikahan "Saya memahami kondisi isteri saya yang sibuk bekerja".

Ketiga skala memiliki reliabilitas yang tinggi, untuk skala komunikasi interpersonal reliabilitasnya 0,855 , skala komitmen reliabilitasnya 0,893 dan skala kepuasan pernikahan reliabilitasnya 0,903 .

Tabel 1. Hasil uji hipotesis regresi ganda

\begin{tabular}{lcccc}
\hline \multicolumn{1}{c}{ Model } & $\boldsymbol{R}$ Square & $\begin{array}{c}\text { Adjusted } \boldsymbol{R} \\
\text { Square }\end{array}$ & $\boldsymbol{F}$ & Sig \\
\hline $\begin{array}{l}\text { Komimen, komunikasi } \\
\text { interpersonal dengan } \\
\text { kepuasan pernikahan }\end{array}$ & 0,222 & 0,208 & 15,284 & 0,000 \\
\hline
\end{tabular}

Berdasarkan hasil analisis regresi ganda diperoleh koefisien korelasi $\mathrm{F}$ sebesar 15,824 dengan signifikansi (p) 0,000, maka $p \leq 0,01$. Adapun ketentuan diterima atau ditolak sebuah hipotesis apabila signifikansi lebih kecil atau sama dengan $0,05(p \leq 0,01)$, dengan demikian maka dapat disimpulkan hipotesis dalam penelitian ini diterima. Artinya terdapat hubungan antara komimen dan komunikasi interpersonaldengan kepuasan pernikahan.

\section{Pembahasan}

Hasil penelitian menunjukkan terdapat hubunganantara komitmen dan komunikasi interpersonal dengan kepuasan pernikahan pada suami yang memiliki istri bekerja dengan signifikansi sebesar $0,000(p<0,01)$ dan nilai $F$ sebesar 15,824. Dengan demikian hipotesis dalam penelitian ini diterima. Hasil penelitian yang telah dilakukan oleh penelitimenunjukkan adanya hubungan antara komitmen dan komunikasi interpersonal dengan kepuasan pernikahan pada suami yang memiliki istri bekerja. Hubungan antara komitmen dengan kepuasan pernikahan pada suami yang memiliki istri bekerja juga menunjukkan adanya hubungan. Komitmen memiliki hubungan dengan kepuasan pernikahan. Komitmen pernikahan dibangunsejak sebelum menikah, melalui tahapan ketertarikan pada pasangan, pembuatankesepakatan, dan upaya menghadapi tantangan. Setelah menikahpembentukan komitmen dapat dilihat dari pembagian peran, kesepakatan yang dibuat untuk meminimalisir dampak negatif yang disesuaikan kebutuhan bersama, motivasi istri bekerja, sedikitnya dampak negatif dan semakin meningkatnya dampak positif, sedikitnya permasalahan, dan penyelesaianya melibatkan kerjasama.

Komitmen merupakan faktor penting keberhasilan pernikahan. Adapun kepuasan dalam pernikahan merupakan konstruk yang berpengaruh dalam tingkat komitmen dalam pernikahan. Kepuasan dalam pernikahan yang semakin meningkat akan semakin memperkokoh pernikahan. Meningkatnya kepuasan dalam pernikahan akan meningkatnya komitmen dalam pernikahan. Hal ini ditunjukkan berdasarkan hasil pada penelitian ini bahwa suami yang memiliki istri bekerja akan setia kepada istrinya. Selain 
itu, suami juga memiliki komitmen bahwa tidak akan meninggalkan pasangan sampai maut yang memisahkan suami juga memiliki pemikiran sebesar apapun pertengkaran pasangan berjanji tidak akan mengatakan perpisahan demi menjaga nama baik.

Hal tersebut sesuai dengan pendapat Papalia, Olds dan Feldman, (2008) yang mengatakan bahwa salah satu faktor terpenting kesuksesan pernikahan adalah perasaan akan adanya komitmen. Hubungan antara komunikasi interpersonal dengan kepuasan pernikahan pada suami yang memiliki istri bekerja ditunjukkan dengan tingkat signifikansi sebesar $0,000 \quad(p<0,05)$ dengan nilai $F$ sebesar 4,549. Artinya komunikasi interpersonal memiliki hubungan dengan kepuasan pernikahan. Kemampuan seseoranguntukmengungkapkanide,gagasan dan pemikirannya akan sangat menentukan hubungan interpesonalnya, semakin baik seseorang mengungkapkannya berarti akan semakin baik pula hubungan interpesonalnya terutama dalam hal ini dengan pasangannya (Olson dan Fowers 2010). Hal ini nampaknya membuat keterampilan komunikasi interpersonal memiliki sumbangan dalam menentukan kepuasan dalam hubungan pernikahan. Dalam interaksi yang panjang dan menyangkut tugas perkembangan inilah menuntut individu untuk mampu melakukan kesepakatan-kesepakatan tertentu agar sukses menjalankan tugas perkembangannya. Ketidakberhasilan dalam melakukan interaksi yang baik akan membuat hubungan pernikahan menjadi kurang harmonis dan bahkan berujung pada perceraian.

Menurut Surya (2001) salah satu cara yang dapat dilakukan istri yang bekerja untuk bisa sukses dalam membangun rumah tangga adalah dengan melakukan penyesuaian antara diri dengan pekerjaan, yang disertai dukungan dari suami. Dukungan tersebut dapat dikembangkan melalui komunikasi interpersonal yang efektif antara suami dan istri. Keterampilan komunikasi merupakan keterampilan diadik yang perlu dikembangkan oleh pasangan, keduanya perlu bersinergi untuk membangun komunikasi yang baik. Komunikasi dan interaksi suami istri dalam kehidupan sehari-hari dapat mempengaruhi komitmen pernikahan dalam keluarga. Komunikasi sehari-hari dapat meningkatkan keintiman, kepercayaan, dan persahabatan dengan pasangannya (Weigel dalam Latifatunnikmah \& Lestari , 2017).

Komunikasi merupakan cara efektif yang dapat dilakukan pasangan suami istri sehingga dapat menghindari diri dari situasi yang dapat merusak hubungan pernikahan. Suami merasa mampu dan bertanggung jawab untuk memenuhi semua kebutuhan istri dan anak-anaknya sehingga istri tidak perlu lagi untuk bekerja diluar rumah. Memenuhi semua kebutuhan istri dan anak-anak juga merupakan salah satu komitmen suami diawal pernikahan.

Berdasarkan hasil penelitian ini, bahwa terdapat hubungan antara komitmen dan komunikasi interpersonal dengan kepuasan dalam hubungan pernikahan, dapat dijelaskan bahwa pasangan dengan komitmen yang tinggi akan berusaha untuk mempertahankan hubungan. Selalu mengkomunikasikan segala permasalahan yang ada didalam pernikahan, berusaha untuk mencari solusi dan memecahkan masalah secara lebih efektif akan cenderung lebih baik, lebih puas dengan kehidupan daripada pasangan yang komitmennya rendah. Suami mempunyai rasa percaya untuk mengandalkan perilaku pasangan untuk mencapai tujuan yang dikehendaki, menaruh kepercayaan kepada pasangan. Bersikap jujur dan berempati. Menerima dan memahami persoalan dalam bermacam sudut dengan sikap terbuka terhadap pasangan.

Komitmen dengan kepuasan pernikahan memperoleh nilai Beta $=0,433$ dan $p=0,000(p<0,05)$ sedangkan komunikasi dengan kepuasan pernikahan memperoleh nilai Beta $=0,128$ dan $p=0,142(p<0,05)$ hal ini menjelaskan bahwa variabel komitmen lebih mampu memprediksi kepuasan pernikahan pada suami yang memiliki istri bekerja dibandingkan variabel komunikasi interpersonal.

Salah satu karakteristik pernikahan yang memuaskan adalah adanya komitmen yang tidak hanya ditujukan terhadap 
pernikahan sebagai sebuah intuisi, tetapi juga terhadap pasangannya. Beberapa pasangan berkomitmen terhadap perkembangan hubungan pernikahannya, antara lain kematangan hubungan, penyesuaian diri dengan pasangan, perkembangan pasangan, serta terhadap pengalaman dan situasi baru yang dialami pasangan. Komitmen yang kuat dengan pasangan dapat menjaga stabilitas pernikahan, oleh karena itu komitmen dijadikan sebagai strategi dalam melanjutkan hubungan dengan penuh usaha dan biaya. Suami yang memiliki komitmen pernikahan terhadap pasangan akan setia kepada istrinya. Selain itu, suami tidak akan meninggalkan pasangan sampai maut memisahkan. Kemampuan saling mempertahankan dengan pasangan akan membuat komunikasi dengan pasangan terbuka dan setara, pengungkapan kasih sayang dilakukan secara verbal dan non verbal, banyaknya waktu bersama pasangan, mampu menerima kekurangan pasangan baik secara penyesuaian maupun sebagai konsekuensi dari komitmen dan kerelan berkorban untuk pasangan yang lebih.

Komunikasi interpersonal dianggap berperan dalam membantu dan meningkatkan kepuasan pernikahan pada suami yang memiliki istribekerja. Komunikasi interpersonal yang baik akan meningkatkan kualitas suatu hubungan kearah yang lebih baik dan penting bagi kebahagiaan hidup. Kemampuan mempertahankan dan interaksi yang baik dengan pasangan akan berhubungan dengan pencapaian kepuasan pernikahan yang ditandai dengan adanya kemampu menerima kelebihan dan kekurangan satu sama lain, setia dengan janji pernikahan yang telah diucapkan, menjaga nama baik pernikahan, merasa nyaman menjalani kehidupan pernikahan, adanya keintiman fisik dalam pernikahan, saling mendukung dan fleksibel, dan pasangan memiliki kesadaran untuk saling menjaga komunikasi.

\section{Kesimpulan}

Berdasarkan hasil penelitian dan pembahasan dalam penelitian, dapat ditarik kesimpulan bahwa komitmen yang terbentuk dalam hubungan suami dan istri serta adanya komunikasi interpersonal yang baik, maka akan meningkatkan kepuasan pernikahan pada suami yang memiliki istri bekerja. Dengan demikian hipotesis dalam penelitian ini diterima. Artinya ada hubungan antara komitmen dan komunikasi interpersonal dengan kepuasan pernikahan pada suami yang memiliki istri bekerja.

\section{Daftar Pustaka}

Ardhianita, I \& Andayani, B. (2004). Kepuasan Penikahan di Tinjau Dari Berpacaran dan Tidak Berpacaran. Jurnal Psikologi, $32,(2), 101-111$.

Arikunto, S. (2002). Prosedur Penelitian, Suatu Pendekatan Praktek. Jakarta: Rineka Cipta.

Aqmalia. (2009). Kepuasan Pernikahan pada Pekerja Seks Komersial (PSK). JurnalUniversitas Gunadarma. http://www. gunadarma.ac.id/library/ articles/graduate/psychology/2009/ Artikel_10503148.pdf.

Azeez, A.E.P (2013) Employed Women and Marital Satisfaction: A Study among Female Nurses., International Journal of Management and Social Sciences Research, 2(11)17-22.

Azwar, S. (2009). Reliabilitas dan Validitas. Yogyakarta: Pustaka Pelajar Offset.

. (2010). Penyusunan Skala Psikologi. Yogyakarta: Pustaka Pelajar Offset.

. (2012). Penyusunan Skala Psikologis. Yogyakarta: Pustaka Pelajar. Badan Pusat Statistik 2015. Ketenagakerjaan. www.bps.go.id

Boseke, R. O. (2015). Hubungan Antara Komitmen Pernikahan dengan Kepuasan Pernikahan pada istri yang ditinggal suami bekerja diluar kota. Skripsi. Salatiga:Fakultas Psikologi.

Canel, A. (2013). Development of the Material Satisfaction Scale. Education Sciences; Theory \& Practice.

Daeng, N. R. (2010). Perbedaan Kepuasan Pernikahan Antara Suami Dan I s t $r$ i 
dalam Dual Career Family. Skripsi. Medan: Fakultas Psikologi.

Dalimunte, M.R. (2013). Kepuasan Pernikahan Pada Pasangan Suami dan Istri Yang Terlibat dalam Dual Career Family (Studi Kasus Pada Tiga Pasangan Suami Istri Di Kota Bandung). Skripsi. Bandung: Program Studi Psikologi Fakultas IImu Pendidikan.

Desmayanti, S. (2009). Hubungan Antara Resolusi Konflik dan Kepuasan Pernikahan pada Pasangan Suami Istri Bekerja pada Masa Awal Pernikahan. Skripsi. Jakarta: Fakultas Psikologi Universitas Indonesia.

Devito, J.(1997). Komunikasi antar manusia (terjemahan).Alih bahasa Ir. Agus Maulana MSM.Jakarta: Professional Books.

Dewi, N. R \& Sudhana, H. (2013). Hubungan Antara Komunikasi Interpersonal Pasutrii dengan Keharmonisan dalam Pernikahan. Jurnal Psikologi Udayana, 1(1), 22-23.

Dewi,I. S. (2006). Kesiapan Menikah pada Wanita Dewasa Awal yang Bekerja. Skripsi. Medan: Program Studi Psikologi Fakultas Kedokteran Universitas

Hartono, (2008). Spss 16.0. Analisis data Statistik dan Penelitian. Yogyakarta: Pustaka Pelajar.

Handayani, M.M. (2008). Psikologi Keluarga. Surabaya: Fakultas Psikologi Universitas Airlangga.

Hurlock, E. B. (1980). Psikologi Perkembangan suatu pendekatan sepanjamg rentang kehidupan. Alih bahasa Dra. Istiwidayanti dan Drs. Soedjarwo, M.Sc. Jakarta: Erlangga.

Idrus, M. (2009). Metode Penelitian IImu Sosial (Pendekatan Kualitatif dan Kuantitatif). Jakarta: Erlangga.

Johnson, M. P. (1991). Commitment to Personal Relationships. In W. H. Jones \& D. W. Perlman (Eds.), Advances in Personal Relationships. Vol. 3, 117-143. London: Jessica Kingsley Publishers.

Kartono, K. (1985). Menyiapkan dan memandu karier. Jakarta: Penerbit CV. Rajawali.
Lambert, N. M., \& Dollahite, D. C. (2008P. The Threefold Cord: Marital Commitment in Religious Couple. Journal of Family Issues, 29, 592-614.

Latifatunnikmah \& Lestari.S. (2017). Komitmen Pernikahan pada Pasangan Suami Istri Bekerja. Humanitas, 14,(2), 103-119.

Liliweri, A. (1997). Komunikasi antarpribadi. Bandung: PT. Citra Aditya Bakti.

Lavenson, R.W., Carstensen, L.L, \& Gottman, J.M. (1993). The influence of age and gender on affect, physiology, and their interrelations: A study of longterm marriages. Journal of Personality and Social Psychology, 67, 56-58.

Muslihah, U. N. (2014). Hubungan antara Kemampuan Komunikasi Interpersonal dengan Kepuasan Pernikahan Pada Istri dan Suami di Usia Awal Pernikahan di Kota Bandung. Jurnal Psikologi Universitas Pendidikan Indonesia. Vol 01, No. 1, 22-23.

Olson, D.H \& Fowers, B. J, (2010). Marriages and Families Strengths 7th ed. New York: McGraw-Hill.

Papalia, E. D., Old, S. W., Feldman, R. D. (2008). Human Development (Psikologi Perkembangan) Edisi Kesembilan. Alih bahasa A. K. Anwar. Jakarta: Kencana.

Paputungan, F. (2012). Kepuasan Pernikahan Suami Yang Memiliki Istri Berkarir. http:// psikologi.ub.ac.id/wp content/uploads/2013/10/JURNAL5.pdf.

Pertiwi, S. (2006). Hubungan antara Harga Diri dan Efektivitas Komunikasi Suami Istri dengan Kecemasan Suami yang Istrinya Berpenghasilan Lebih Tinggi.Skripsi tidak diterbitkan.Fakultas Psikologi UII Yogyakarta.

Rini, K. Q \& Retnaningsih. (2008). Kontribusi Self Disclosure Pada Kepuasan Perkawinan Pria Dewasa Awal. Jurnal Psikologi, 1 (2), 152-157.

Robinson, L.C \& Blanton, P. W. (2003). Material Strengths In Enduring Marriages. Journal of Family Relations, Volume 42, Hal. 38-4.

Rusbult, C.E., Johnson .D.J., \& Morrow, G.D. (1986). Predicting Satisfaction and Commitment in Adult Romantic 
Involvements: An Assessment of the Generalizability of the Investment Model. Social Psychology Quarterly, 49, (1) 8189

Santock, W. J. (2002). Life Span Development (Jilid II). Alih bahasa Ahcmad Chusairi dan Juda Damanik. Jakarta: Erlangga.

Sastropoetro. (1986). Partisipasi, Komunikasi, PersuasidanDisiplindalamPembangunan Nasional. Bandung: Penerbit Alumni.

Suardiman. (1991). Psikologi Konseling. Yogyakarta: Percetakan study.

Surya, M. (2001). Bina Keluarga. Semarang: CV Aneka IImu.

Sugiyono. 2011. Metode Penelitian Kuantitatif dan Kualitatif (Riset dan Development). Bandung: Penerbit Alfabeta.

Tan. (1981). Pengantar Teori \& Manajemen Komunikasi. Jakarta - Jurnal Press.

Thompson-Hayes, M., \& Webb, L. M. (2004). Commitment Under Construction:A Dyadic and Communicative Model of Marital Commitment. The Journal of Family Communication ,4:3-4. 249-260.

Wulandari, D. A. (2014). Komitmen Pada Perkawinan Ditinjau dari Kepuasan dalam Perkawinan. Prosiding Seminar Hasil Penelitian LPPM UMP. Universitas Muhammadiyah Purwokerto. 